\title{
Neuronal Ceroid Lipofuscinosis Type 4B
}

National Cancer Institute

\section{Source}

National Cancer Institute. Neuronal Ceroid Lipofuscinosis Type 4B. NCI Thesaurus. Code C128116.

A condition associated with mutation(s) in the DNAJC5 gene, encoding dnaj homolog subfamily $\mathrm{C}$ member 5 . The condition is one of a group of genetically heterogeneous neurodeg enerative disorders, characterized by accumulation of intracellular lipopigments. 